\title{
THE TRADITION OF GIVING CALIPHATE IN THE SECTS
}

\section{ZEHRA HAMARAT *}

\section{* İSTANBUL ÜNIVERSİTESİ EDEBİYAT FAKÜLTESİ}

E-mail: hamarat.zehra@hotmail.com

Copyright (C) 2015 ZEHRA HAMARAT. This is an open access article distributed under the Eurasian Academy of Sciences License, which permits unrestricted use, distribution, and reproduction in any medium, provided the original work is properly cited.

\begin{abstract}
Due to the fact that the continuity of sect organization, its force and diffussion process of a great populace are directly related to the tradition of giving caliphate, in order to make sense of hierarchical system and organizational structure of sect, and to reveal the function and force in the community and among the other organization of sect, aspects of religious-sufistic of this tradition requires to be analyzed with dimensions of sociologic and psychologic. To make a deeply and inclusive study about this subject is dependent on examining this tradition in the forms of implementation and perception in all sects. In this article, written up with the aim of prologuizing such a long-termed study, the tradition of giving caliphate in the sect of BayramiŞemsi is dealt with and the written texts are used as materials. In this study, within the information that written texts give, the basis of this tradition based on Islamic framework, the conditions and the times of being caliphate, what caliphate is symbolized and the tradition that undertakes especially functions of organizational structure are dealt with. As a result, it is reached the findings that being related to these conditions, a certain type of people is idealized in the organization and at the same time in the community, as this implementation being so important for the continuity of organizational structure regardless of coincidence is attached to certain conditions, this tradition, by being based upon a divine basis is provided sacredness and composed legitimacy platform.
\end{abstract}

Keywords: sect, caliph, giving caliphate, caliphate symbols, religious leader

\section{Tarikatlarda Hilafet Verme Geleneği}

\section{ÖZET}

Tarikat örgütlenmesinin devamlılı̆̆ı, nüfuzu ve büyük bir kitleye yayılma süreçleri hilafet verme geleneği ile doğrudan ilgili olduğundan tarikatın örgütsel yapısını ve hiyerarşik sistemini anlamlandırabilmek, diğer örgütlenmeler arasındaki ve toplum içindeki nüfuzu ve işlevini ortaya koyabilmek için bu geleneğin dinî-tasavvufi yönleri, sosyolojik ve psikolojik boyutları ile incelenmesi gerekmektedir. Konuyla ilgili derinlemesine ve kapsayıcı bir çalışma yapmak, bu geleneğin bütün tarikatlardaki algılanma ve uygulanma biçimlerinin araştırılmasına bağlıdır. Böyle uzun soluklu bir çalışmaya giriş yapmak amacı ile kaleme alınan bu makalede BayramîŞemsî tarikatında hilafet verme geleneği ele alınmış ve tarikatın yazılı metinleri materyal olarak kullanılmıştır. Yazılı metinlerin verdiği bilgiler dahilinde geleneğin İslami çerçevede dayandırıldığ temel, halife olabilmenin şartları ve zamanı, halifeliğin nelerle simgelendiği ve geleneğin özellikle örgütsel yapıda üstlendiği işlevler bu çalışmada ele alınmıştır. Sonuç olarak, bu geleneğe ilahi bir temele dayandırılarak kutsallık sağlandığı ve meşruiyet zemini oluşturulduğu, örgütsel yapının sürekliliği için çok önemli olan bu uygulamanın tesadüfe 
bırakılmayıp belli şartlara bağlandığı, bu şartlarla ilgili olarak belli bir insan tipinin örgüt içinde ve aynı zamanda toplumda idealleştirildiği bulgularına ulaşılmıştır.

Anahtar Kelimeler: tarikat, halife, hilafet verme, hilafet simgeleri, dini lider

\section{Giriş}

Halife, siyaset alanında ve tasavvufta yaygın olarak kullanılan bir terimdir (Uludağ, 1997: 299). Tasavvufi bir terim olarak kullanılmadan önce bu kavram fikıhçılar ve kelam alimleri tarafından özellikle siyasi alanın konusu olarak ele alınmış ve tartışılmıştır. Bu kavrama fikıhçıların kazandırdığı açıklamalar ve sonraki süreçte yaşanan tarihî ve siyasi gelişmelerle kavramın uğradığı değişim ve dönüşüm, tasavvufi alandaki kullanımını anlamamız açısından da önemlidir.

Fıkıhçılara göre halife Hz. Muhammed'in halefi olarak Müslümanlara hem dinî hem de dünyevi işlerinde başkanlık eden, Müslümanlar üzerinde genel anlamda tasarruf yetkisi bulunan kişidir. Halife, başlangıçta siyasi iktidarı temsil etmekteyken zamanla manevi otorite anlamını da kazanmış, hatta yaşanan siyasi ve tarihî gelişmeler neticesinde sadece manevi otoriteyi temsil eder hale gelmiştir. Halife, ister siyasi ister manevi iktidarı temsil ettiği süreçte olsun bütün Müslümanlar üzerinde tasarruf yetkisi bulunduğu algısını koruduğundan evrensel niteliğini kaybetmemiştir (Türcan, 2007: 297-304).

Tasavvufi bir terim olarak halife kavramına baktığımızda ise bu kavramın teorik planda genellikle manevi alanın konusu olarak işlendiğini ve pratikte halifenin iktidarının siyasi alandaki gibi evrensel olmayıp belli bir örgüt ${ }^{2}$ ile sınırlandığını görmekteyiz.

Bu kavramın tasavvufi bir terim olarak ortaya çıkışı insan-1 kamil ve kutup fikirlerinin gelişmesiyle bağlantılıdır. Halife kavramına ilk olarak Gazalî (ö. 1111) tasavvufi bir anlam yüklemiş, Muhyiddin Arabî (ö. 1240) ve takipçileri de bu terimi tasavvufun temel kavramlarından biri haline getirmiştir. Bu kavram tasavvufta şeyh adına müritleri yetiştirme ve diğer insanları terbiye etme yetkisine sahip olan ve şeyh öldükten sonra şeyhlik makamına geçme yetkisi bulunan kişi anlamında kullanılmaktadır. Müride bu yetki belli makamları aştıktan sonra şeyhi tarafından verilmektedir (Uludağ, 1997: 299-300).

Halife teriminin tasavvufi alandaki bu kullanımı birinin yerine geçip görevlerini ifa eden, yerini dolduran, ardılı olan; birini temsil eden bir kişiliği karşımıza çıkardığından daha önce gerçekleştirilmiş bir tecrübeye ve otoritenin görevlerini üstlenmeye vurgu yapmaktadır (Uludağ, 1997: 299; Cebecioğlu,

\footnotetext{
${ }^{1}$ Ayrica bkz.: (Hoylad1, 2015: 19-21).

${ }^{2} \mathrm{Bu}$ çalışmada tarikat için örgüt kavramı ortak bir amacı gerçekleştirmek için bir araya gelen insanlardan oluşan, kendine has kuralları bulunan ve bu kuralların uygulanması noktasında insanların bir lider etrafinda toplandığ gruplar anlamında kullanılmıştır. Dolayısıyla bu örgütler, gelişen sanayinin ve modern zihniyetin ortaya çıkardığ örgütlerden farklıdır. Kavramın açıklaması için bkz.: (Weber, 2004: 103-105; Kızılçelik vd., 1994: 321-322; Schein, 1978: 8-9). Bu anlamdan hareketle tarikatlar da Allah'a ulaşmak amacıyla şeyh adı verilen bir lider etrafında toplanıp tasavvufun idealize ettiği yaşamı belli kurallar çerçevesinde gerçekleştirmeye çalışan dervişlerin birlikteliğinden meydana gelmiş dinî-tasavvufi örgütler olarak düşünülmüş̧ür. Tarikatın nasıl bir örgüt olduğuna dair ayrıca bkz.: (Güngör, 1982: 98-99, 107-108; Uludağ, 2006: 254-255; Freyer, 1964: 52-53, 61-62).
} 
2004: 245; Hoyladı, 2015: 19). Bu yönüyle de ister siyasi ister tasavvufi alanda olsun her halükarda bir çeşit iktidar biçimini akla getirmektedir. Ancak bu iktidar biçimi tasavvufi alanda halifenin mensup olduğu örgütlenme ile sınırlıdır. Halife mensup olduğu örgüt üyeleri üzerinde tasarrufa sahiptir ve bu yönüyle siyasi alandaki gibi evrensel manada bir hilafetten söz edilememektedir.

Tasavvufun zaman içinde örgütlenmesi ile oluşan tarikatlarda halifelik çeşitli şekillerde karşımıza çıkmaktadır. Tarikatta şeyh bazen uygun gördüğü kişiye iktidarını ve tasarruf hakkını tamamen devretmekte bazen de müridine sınırlı olarak yetki vermektedir. Bu yetki devri ve iktidarın kaynağına göre müridin halifeliği şekli hilafet, manevi hilafet ve hakiki hilafet şeklinde isimlendirilmektedir. Şekli halifeler tekkenin ve tekkede görevli olan dervişlerin yönetilmesi ile ilgilenmektedir. Bu halifelerin alim olmasına ya da seyrü süluk usulünü bilmesine gerek yoktur, iyi bir yönetici olmaları yeterlidir. Şeyh öldükten sonra yerine geçen oğullarının halifeliği genellikle bu tür bir halifeliktir. Mürit sülukunu tamamladıktan sonra şeyhinden irşat izni alarak halife olmuşsa ona da manevî halife denilmektedir. Bu tür bir hilafette müridin tarikat eğitimini şeyhi gözetiminde tamamlaması ve halife olması için belli bir makama ulaşması gerekmektedir. Kişinin bizzat Allah tarafından irşat için görevlendirilmesi ile elde edilen hilafete ise hakiki hilafet denildiği belirtilmektedir. Bazı müritler halifeliğin bu üç mertebesine de ulaşabilmektedir (Uludağ, 1997: 300).

Tarikatlarda halifeliğin çeşitlenmesinde dikkat çeken bir husus da her halifenin şeyh olma yeterliliğine sahip olup olmadığıdır. Buna göre şeyh olma yeterliliğine sahip olan müride verilen hilafete hilafet-i tamme denilmektedir. Hilafet-i nakısa ise şeyhlik yetkisi bulunmayan ve müritlerin derslerini takip edip seyrü süluku tamamlatmakla görevli olan müride verilen hilafettir (Cebecioğlu, 2004: 245246).

Halifeliğin tarikatlarda duruma göre çeşitlenmiş olması ve farklı şekillerde isimlendirilmesi, hilafet verme geleneğinin bu örgütlenmeler için pek çok yönden fonksiyonel olduğuna da işaret etmektedir. Bu geleneğin tarikatlar için önemli bir fonksiyonu bu örgütlenmelerin temel karakteristiğini oluşturan ilke ve kuralları, inanç ve uygulamaları ile varlığını ve bütünlüğünü sürdürmesine yardımcı olmasıdır. Tarikatın geniş bir coğrafyaya yayılmasında, yeni tekke ve dervişleri ile şubelerinin oluşturulmasında da şeyh adına irşat faaliyetinde bulunan halifeler rol oynamaktadır. Tarikat örgütlenmesinin sürekliliği, nüfuzu, popülerliği gibi konular halifeliği sadece dinî-tasavvufi yönleri ile değil; sosyolojik yönleri ile de ele almayı gerektirmektedir. Ayrıca örgütün diğer örgütlenmeler ve toplum ile olan ilişkisinde halifelerin üstlendiği rol de konuyu sosyolojik anlamda önemli kılmaktadır. Halifelerin diğer insanlarla olan ilişkisi ve halifelik geleneğinin birey açısından taşıdığı önem ise konuyu psikolojik boyutları ile ele almayı gerektirmektedir.

Hilafet verme geleneğinin söz konusu boyutları ile ele alınması tarikatların örgütlenme ve liderlik $^{3}$ süreçleri, bu örgütlenmelerin yapıları ve hiyerarşik sistemleri, örgüt içi iktidar-güç ilişkileri hakkında da birtakım izlenimler oluşturacaktır. İleride yapılacak böyle bütüncül bir araştırmaya hazırlık olarak kaleme alınan bu çalışma, Bayramî tarikatının Akşemseddin (ö. 1459) tarafından kurulan

\footnotetext{
${ }^{3} \mathrm{Bu}$ çalışmada şeyh için lider kavramı sahip olduğu güç, ün veya statü dolayısıyla tarikatta neyin nasıl yapılacağını koordine eden ve bunun için somut modeller sunan; belli bir amaca ulaşmak için insanları yöneten, denetleyen; insanların tutum ve davranışlarını etkileyen kişi anlamında kullanılmıştır. Lider (önder) kavramının bazı anlamları için bkz.: (Krech vd., 1971: 252; Zel, 2006: 110; Bilgin, 2003: 218-219; Ozankaya, 1975: 77; Freedman vd., 2003: 539; Türkçe Sözlük, 2011: 1585-1586, 1852).
} 
Bayramî-Şemsî kolu ile sınırlandırılmış ve tarikatın yazılı metinlerinde verilen bilgilerden hareketle tespitler gerçekleştirilmiştir. Bayramî-Melamîler ise bu çalışmanın dışında tutulmuş ancak Melamîlere ait kaynaklar konuyla ilgileri nispetinde kullanılmıştır.

Bayramî tarikatının Melamî kolunda kuralları belli bir mürşit-mürit ilişkisi ile açık ve ritüellere bağlı bir halife tayin etme geleneğinden söz edilememektedir. Klasik anlamda bir tarikat yapılanması bulunmayan Melamîliğin esasında şeyhlik kurumu da yer almamaktadır. Başta bulunan kutup ise geleneksel tarikatlardaki şeyh ve halifelerden daha üstün bir konuma sahiptir (Işın, 1994: 381; Ocak, 1998: 254).

\section{Hilafet Verme Geleneğinin Dayandırıldığı Temel: Kutsallaştırma ve Meşrulaştırma Çabaları}

Tarikatta mutasavvıfların kendilerini bir yere bağlama gayretlerinin ve silsile arayışlarının XI. yüzyılda başladığı; buna bağlı olarak gelişen hilafet verme geleneğinin ise XII. yüzyılın sonunda ortaya çıktığı tahmin edilmektedir (Akpınar, 2000: 397).

Tarikatlarda hilafet verme uygulamasının çeşitli yönleri ile İslami çerçevede belli bir temele dayandırıldığ 1 görülmektedir. Bu uygulamaya İslami çerçevede bir temel arayışı meşruiyet kazandırma gayreti olarak değerlendirilebilir. Zira tarikat mensupları, birtakım inanç ve uygulamalarının peygamber zamanında olmaması veya İslam'la ilgisi bulunmaması gerekçesi ile eleştirilmişlerdir. Hilafet verme uygulamasına böyle bir temel arayışının bu eleştirilerle de ilgisinin bulunduğu düşünülebilir.

Hilafet verme geleneği incelediğimiz metinlerde Hz. Muhammed'in bir uygulamasına dayandırılmakta ve tarikatta silsile halinde haleflere aktarılan gizli ilmin de bizzat Allah tarafindan $\mathrm{Hz}$. Muhammed'e gönderildiği belirtilmektedir. Böylece hem kutsal bilgiye sahip olan kişi yani halef kutsallaştırılmakta hem de halef bırakma uygulaması sünnet olarak algılanmaktadır. Hz. Muhammed'in halef bırakma uygulaması ve Allah'ın gönderdiği gizli ilim, metinde Mecdüddin İsa (ö. 1531) tarafindan şöyle aktarılmaktadır:

Hak celle ve alâ habîbi Muhammed Mustafa sallallahu aleyhi ve sellem hazretlerine Cebrail aleyhisellatü vesselâm ile gönderdiği kelime-i şehâdet ve telkîn-i zikr ve ilm-i ahfâ ve hakâyık ve dakâyık ve ta'bîrât ve te'vîlât ve teveccüh ve tasarruf ve ilhâm-1 rabbânî ne ise bil cümle fahri âlem hazreti Muhammed Mustafa sallallâhu aleyhi ve sellem Ali kerremallâhu veche hakkında ente minnî ve ene mink ${ }^{5}$ deyip üç kere zikr-i darbı ta'lîm ettirip tertîb-i vilâyet ve kerâmet ve ilm-i hafî neyse edeb-i hilâfet ile bildirdi ve seccâde-i vilâyeti ona lâyık gördü. Onun için silsilei meşâyıhda halîfe-i evvel hazreti Ali' dir. ${ }^{6}$

\footnotetext{
${ }^{4}$ Mecdüddin İsa: H. 851'de (M. 1447) doğmuştur. Şeyh Kasım'ın halifesidir. Tarikatın geniş bir coğrafyaya yayılmasında önemli hizmetleri olmuştur. Pek çok halife yetiştirmiştir. Bkz. İlyas b. İsa Saruhani, Menâkıb-ı Mecdeddîn ve Âdâb-ı Sâlikîn, Müst. Ahmed, 265x160 mm., 19 satır, H.1161, Mısır Milli Kütüphanesi Türkçe Yazmaları, ez-Zekiye-Mahtutatu Farisiyye ve Türkiyye, vr. 1b-3a, 8b, 17a, 42a, 46b, 88a-88b, 104b, 109a-109b, 110b, 111a, 120a-120b.

${ }^{5}$ Ente minnî ve ene minke: Sen bendensin, ben de sendenim (Yılmaz, 2008: 186).

${ }^{6}$ İlyas b. İsa Saruhani, Menâkıb-ı Mecdeddîn ve Âdâb-ı Sâlikîn, vr. 17b. Ayrıca bkz. vr. 72a. Şeyhler de müritlerine hilafet verirken kendileri ile müritleri arasındaki yakınlığı Hz. Muhammed ile Hz. Ali arasındaki bu
} 
Allah'ın gönderdiği bu bilgiler aynı zamanda tarikatlardaki bazı inanç ve uygulamaların da esasını ve temelini oluşturmaktadır. Bu özel bilgiyi Hz. Muhammed'in Hz. Ali’ye naklettiği ve bu konuda onu kendisine halef kıldığı belirtilmektedir. Hz. Muhammed'in Hz. Ali' yi kendisiyle bir tutmas1 ve bu mertebeye en uygun kişi olarak onu görmesi, hilafet verilecek konuda halefle selef arasında özdeşleşme ${ }^{7}$ düzeyinde bir ilişkinin ve benzerliğin mevcudiyetini göstermektedir. Böylece bütün şeyhler de silsile itibariyle Hz. Muhammed'in halifesi olmakta, onunla belli konularda özdeşleşmekte ve hem saygın hem de kutsal bir statü elde etmektedir.

\section{Halife Olabilmenin Şartları ve Zamanı}

Halife, şeyhin vekili olan ve şeyh öldükten sonra onun karizmasıyla birlikte görevlerini de devralan kişidir. Bu nedenle şeyh, bildiği bütün her şeyi aktardığı, kendisiyle aynı manevi olgunluğa ve makama ulaştı̆̆ını düşündüğü müridine hilafet vermektedir. Tarikat eğitimini şeyhin uygun gördüğü şekilde tamamlayıp şeyhin bulunduğu makama ulaşmak halife olabilmenin öncelikli şartıdır ve bu makama ulaştığında mürit ile şeyh arasında özdeşleşme de sağlanmaktadır.

Mecdüddin İsa'nın ve Şeyh Hüsam' ${ }^{8}{ }^{8}$ hilafet alma süreçlerinden bahseden menkıbeler hilafet verme geleneğinin tarikat içinde ne kadar önemsendiğini ve şeyhe de bu konuda büyük bir sorumluluğun yüklendiğini göstermektedir. Bayramî tarikatının önemli temsilcilerinden olan Mecdüddin İsa, Şeyh

yakınlığa benzetmiş ve bu hal Hz. Muhammed'in Hz. Ali'ye ente mini ve ena mink dediği haldir demişlerdir. Bkz. İlyas b. İsa Saruhani, Menâkıb-ı Mecdeddîn ve Âdâb-ı Sâlikîn, vr. 7b-8a. Şeyhle mürit arasındaki bu yakınlığın, şeyhlik makamının peygamberlik makamına benzetilerek ortaya koyulması dikkat çekicidir. Uydurma olduğu belirtilen ama tasavvuf kültüründe konuyla ilgili inanışı yansıtan şu hadiste de şeyhlik ile peygamberlik arasındaki bu benzetme karşımıza çıkmaktadır: "kavmi içindeki şeyh, ümmeti içindeki peygamber gibidir." (Öngören, 2010: $50)$.

${ }^{7}$ Özdeşleşme: Kişinin kendini bir başkası ile eş duruma getirmesi, kendini bir başkasına benzetmesidir (Tolan vd., 1985: 21-22). Şeyhle halifesi arasındaki özdeşleşmede de halife bazı kişisel özellikleri ve gerek örgüt içinde gerekse toplumda sahip olduğu değer dolayısıyla davranışlarını, düşünce ve duygularını şeyhe benzetmektedir. Halifenin kendini şeyhe benzetmesi hem tarikat mensuplarının bir beklentisidir hem de böyle bir durum halefin gönüllü tercihidir.

${ }^{8}$ Şeyh Hüsam: Hakkında fazla bir bilgiye ulaşılamayan Şeyh Hüsam'nn Yazıcızade Muhammed (ö. 1451) neslinden olduğu belirtilmektedir. Bayramî tarikatına bağlanmadan önce Gelibolu'da yaşayan Şeyh Hüsam, daha sonra Akhisar'a gelmiş ve Mecdüddin İsa'ya bağlanmıştır. Mecdüddin İsa'nın isteği ile Mısır'a İbrahim Gülşenî’nin yanına gitmiş ve ondan da hilafet almıştır. Rüya tabiri ilminde çok iyi olduğu için İbrahim Gülşenî kendisine Muabbir lakabını vermiş ve bu lakap ile meşhur olmuştur. Şeyh Ali ve Şeyh Muhammed adında iki oğlu olduğu belirtilmektedir ve bu oğulları da Bayramî tarikatına bağlı olarak faaliyet göstermişlerdir. Bayramiye Tarikatı Menakıbı: Hacı Bayram Veli ve Halifeleri: el-Hâcı Bayrâm Sultân, Akşemseddîn, Şeyh İbrâhîm, Şeyh Kâsım Efendi, Şeyh Îsa Efendi, Şeyh Hüsâm Efendi, Şeyh Bahrî Efendi, Şeyh Alî Efendi, Fâtıma-i Menemeniyye, Haz. Zehra Hamarat, İstanbul: Dergâh Yayınları, 2015, s. 22-24. 
Kasım'dan ${ }^{9}$ önce Muhammed Çelebi'ye ${ }^{10}$ intisap etmiş ve tarikat eğitimini ondan almıştır. Ancak ondan aldığı tarikat eğitiminin halifelik yapmaya ve diğer insanları irşat etmeye yeterli olmadığını anlayınca Muhammed Çelebi'ye gidip Bayramî tarikatından başka bir şeyhe intisap etmek ve böylece tarikat eğitimini tamamlayabilmek için izin istemiştir. Muhammed Çelebi "[Sizde noksan varsa] bizde dahi noksan var; zira biz erdiğimiz yere sizi erdirmiş idik." şeklinde karşıllk vermiştir. ${ }^{11}$ Muhammed Çelebi, bildiği her şeyi aktarıp kendi bulunduğu makama ulaştırdıktan sonra Mecdüddin İsa'ya hilafet verdiğinden halifesinin eğitimindeki eksiğin kendisinden kaynaklandığını kabul etmiştir.

Halife olabilmek için tarikat eğitimini tamamlamak yeterli görülmemekte, mürit şeyhle aynı makama ulaştığında hilafeti hak etmektedir. Konuyla ilgili bilgiler Şeyh Hüsam'ın İbrahim Gülşenî’den (ö. 1534) hilafet almasından bahseden anlatıda karşımıza çıkmaktadır. Mecdüddin İsa'nın isteği üzerine Mısır'a İbrahim Gülşenî’nin yanına gidip ona intisap eden Şeyh Hüsam, çok kısa bir zamanda tarikat eğitimini tamamlamış ve İbrahim Gülşenî'den hilafet almıştır. İbrahim Gülşenî, diğer müritlerine uzun zamandır hilafet vermemesine rağmen Şeyh Hüsam'a çok kısa bir zamanda hilafet vermesini Şeyh Hüsam'ın kendi bulunduğu makamların hepsine ulaşması ve onunla kendisi arasında herhangi bir farkın olmaması ile açıklamıştır. ${ }^{12} \mathrm{Bu}$ makama ulaştı̆̆ında müridin eylemleri görünürde kendisine ait olsa da aslında şeyhe ait eylemler olarak kabul edilmektedir. ${ }^{13}$

Şeyhin ve halifesinin bulunduğu makam tecelli-i $\mathrm{Zat}^{14}$ adı verilen makamdır. Müridin bu makama ulaşıp halife olabilmesi için her şeyden önce kamil bir mürşide bağlanması ve onun hizmetinde olması gerekmektedir. Çünkü taliplerin, kendi iradeleriyle Allah'a ulaşamayacakları ve birinin gözetiminde olmadan tarikat eğitiminin zorluklarına sabredemeyecekleri düşünülmektedir. Müridin, kamil mürşidin uygun gördüğü şekilde halvete girip âlem-i melekût makamina ulaşması, kesâfetin letâfete dönüşmesi, daha sonra âlem-i ceberûta ulaşıp fenâ fi's-slfât olması ve tecelli-i Zât'a ulaşması gerekir. Tecelli-i Zat makamına ulaşamayan kişinin halifelik yapması uygun değildir. Taç, hırka, züht ve takva bakımından tarikat ehline benzemek halife olabilmek için yeterli görülmemektedir; halife olmak isteyen kişinin manevi hallerden ve tasavvufi makamlardan haberdar olması, görünürde kalmayıp hakikata ulaşması gerekmektedir. Mecdüddin İsa, Muhammed Çelebi'den hilafet almış olmasına rağmen tecelli-i Zat makamına ulaşamadığını anlayınca halifeliği bırakmış ve eğitimini tamamlamak için uğraşmıştır. ${ }^{15}$

\footnotetext{
${ }^{9}$ Şeyh Kasım: İbrahim Tennurî’nin oğlu ve halifesidir. H. 869'da (M. 1464/65) babasından hilafet almıştır. İlyas b. İ̀a Saruhani, Menâkıb-ı Mecdeddîn ve Âdâb-ı Sâlikîn, vr. 4b-5b, 18a.

${ }^{10}$ Muhammed Çelebi: Bayramî tarikatına mensup olan Carullah Efendi'nin oğludur. Balıkesir taraflarında bir kasabada ikamet etmiştir. İlyas b. İsa Saruhani, Menâkıb-ı Mecdeddîn ve Âdâb-ı Sâlikîn, vr. 2 b.

${ }^{11}$ İlyas b. İsa Saruhani, Menâkıb-ı Mecdeddîn ve Âdâb-ı Sâlikîn, vr. 2b-3b.

${ }^{12}$ Bayramiye Tarikatı Menakıbı: Hacı Bayram Veli ve Halifeleri: el-Hâcı Bayrâm Sultân, Akşemseddîn, Şeyh İbrâhîm, Şeyh Kâsım Efendi, Şeyh Îsa Efendi, Şeyh Hüsâm Efendi, Şeyh Bahrî Efendi, Şeyh Alî Efendi, Fâtıma-i Menemeniyye, s. 64-65.

${ }^{13}$ İlyas b. İsa Saruhani, Menâkıb-ı Mecdeddîn ve Âdâb-ı Sâlikîn, vr. 8a.

${ }^{14}$ Tecelli-i Zat: İlahi zatın kendisi için tecelli etmesidir. Müridin kalbinde Hakk'ın zatının ortaya çıkmasıdır. Bu tecellide sadece Zat ve onun birliği söz konusudur (Uludağ, 2012: 346).

${ }^{15}$ İlyas b. İsa Saruhani, Menâkıb-ı Mecdeddîn ve Âdâb-ı Sâlikîn, vr. 2b, 3b-4a, 38b.
} 
Tarikat eğitimini tamamlamış olmak Bayramî-Şemsî tarikatında hilafet verilecek kişide aranan öncelikli şartlardandır. Tarikat eğitimini tamamlamak şartıyla kadınlar, ümmiler ve âmâlar bile hilafetten tamamen men edilmemişken tarikat eğitimini tamamlamadan hilafet almak isteyen kişi şeyhin oğlu dahi olsa buna müsaade edilmemiştir. Hatta şeyhe, bu konuda vasiyette bulunması ve tarikat eğitimini tamamlamayan oğlunun halifeliğine izin vermemesi tavsiye edilmiştir. ${ }^{16}$

Mürit söz konusu makama şeyhin rehberliğinde ulaşmaktadır. Eğitimin tamamlanma ve müridin halife olma zamanına da şeyh karar vermektedir. Halife olabilmenin belli, standart bir süresi söz konusu değildir. Şeyh, kimi müridine uzun yıllar geçmesine rağmen hilafet vermeyip bazı müridini de çok kısa bir zaman içinde halife tayin edebilmektedir. Şeyh Hüsam'ın İbrahim Gülşenî'den hilafet alışı diğer müritlere göre çok daha kısa bir zamanda gerçekleşmiştir. Aynı şekilde Hacı Bayram Veli (ö. 1429/30) de bazı müritlerine kırk yıl geçmesine rağmen hilafet vermemiş, Akşemseddin'e ise çok kısa bir zamanda hilafet vermiştir. Kısa zamanda hilafet alma müridin sahip olduğu bazı niteliklerle de ilgilidir. Şeyh Hüsam, özellikle manevi olgunluğu ve riyazetteki kabiliyeti; Akşemseddin ise şeyhinden gördüğü ve duyduğu her şeye sorgulamadan hemen inanıp teslim olması ile kısa zaman içinde hilafet makamını elde etmiştir. ${ }^{17}$

\section{Halifeliği Mekruh Olan Kişiler: Zoraki Rehberler}

Halifelik önemli bir makamdır ve şeyh, halife tayin ettiği kişiye bir bakıma tarikat önderliğini de devretmektedir. Bu nedenle Bayramî-Şemsî tarikatında halife tayininde çok dikkatli davranıldığı görülmekte ve bizzat Hz. Muhammed'in Mecdüddin İsa'ya olur olmaz herkese hilafet vermemesi tavsiyesinde bulunduğu belirtilmektedir. ${ }^{18}$

Halife olabilmenin en önemli şartı tarikat eğitimini tamamlamaktır. Bayramî-Şemsî tarikatında eğitimini tamamlayıp belli bir makama ulaşan her mürit, şeyhin uygun görmesi halinde hilafet alabilmekte, bunun haricinde kimse bu makamdan doğrudan men edilmemektedir. Ancak kadınlara, ümmi olanlara, görme engeli bulunanlara ve hünsalara hilafet verilmesi Bayramî-Şemsî tarikatında pek tercih edilen bir durum değildir.

Kadınlara hilafet vermek erkek müritlerden farklı olarak özel bazı şartlara bağlanmıştır. Hilafet verilecek kadın mürit, tarikat eğitimini tamamladıktan sonra uzun yıllar içinde takvası ve edebi ile kendisini ispatlamalıdır. Gerekli şartları sağlamış olsa da genç bir kadına hilafet verilmesi ise caiz değildir. ${ }^{19}$

${ }^{16}$ İlyas b. İsa Saruhani, Menâkıb-ı Mecdeddîn ve Âdâb-ı Sâlikîn, vr. $22 b$.

${ }^{17}$ Bayramiye Tarikatı Menakıbı: Hacı Bayram Veli ve Halifeleri: el-Hâcı Bayrâm Sultân, Akşemseddîn, Şeyh İbrâhîm, Şeyh Kâsım Efendi, Şeyh Îsa Efendi, Şeyh Hüsâm Efendi, Şeyh Bahrî Efendi, Şeyh Alî Efendi, Fâtıma-i Menemeniyye, s. 64-65; Emir Hüseyin Enîsî, Menâkıb-ı Akşemseddîn, Haz. Bilâl Aktan, Mustafa Güneş, İstanbul: H Yayınları, 2011, s. 41.

18 İlyas b. İsa Saruhani, Menâkıb-ı Mecdeddîn ve Âdâb-ı Sâlikîn, vr. 50b.

${ }^{19}$ İlyas b. İsa Saruhani, Menâkıb-ı Mecdeddîn ve Âdâb-ı Sâlikîn, vr. 22a. 
Bayramî tarikatında hilafet verilmesi uygun görülmeyen diğer kişiler de âmâlar, ümmiler ve hünsalardır. Bu kişilere hilafet vermek mekruhtur. Bunların halifelikten tamamen men edilmeyip zaruri haller dışında halifeliklerinin uygun görülmemesi gibi bir durum karşımıza çıkmaktadır. ${ }^{20}$

Ümmilere hilafet verme konusuna Bayramî-Melamîler ise biraz farklı yaklaşmaktadır. Şemsîlere göre ümmilere hilafet vermek mekruhtur ancak düşünceleri ve yaşantısı ile BayramîMelamîliğini kuran Ömer Dede ümmidir. Hatta ümmi olmasına rağmen onun pek çok müntesibinin bulunması kaynaklarda nakledildiğine göre Akşemseddin'i rahatsız etmiş; Akşemseddin, Ömer Dede'ye irşat faaliyetinde bulunmamasını söylemiş ve diğer insanları da böyle ümmi birine bağlanmaktan men etmiştir. $^{21}$

\section{Hilafetin İlanı ve Hilafet Simgeleri: Geleneğin Ritüel Boyutu ve Görünür Kılınması}

Bayramî tarikatında müridin halife olduğu tarikat içinde yapılan belli bir merasimle ilan edilmektedir. Bu merasim şeyhin bulunduğu tekkede, tarikat mensupları eşliğinde ve şeyhin uygun gördüğü zamanda gerçekleşmektedir. Bu merasimin içeriği selef ile halef arasındaki bağı, samimiyeti ve halefin diğer müritler içindeki ayrıcalıklı yerini yansıtmaktadır. Ayrıca merasim diğer müritler arasında gerçekleştirilerek o müridin halife olduğuna diğerleri de şahit tutulmaktadır.

Merasim müridin eğitimini tamamlamasından sonra yapılmaktadır. Şeyh müridin halvetinin tamam olduğuna ve onun belli bir makama ulaştığına karar verince hilafet vermek amacıyla onu yanına çağırmaktadır. Mecdüddin İsa'nın hilafet almaya hak kazandığını düşünen Şeyh Kasım, onu sabah namazı vaktinde yanına çağırıp hilafet vermiştir. Sabah namazı kılınıp vird okunduktan ve zikir yapıldıktan sonra Mecdüddin İsa, Şeyh Kasım'a yaklaşıp elini öpmek istemiş ama Şeyh Kasım, halifesine elini öptürmemiş ve merasim usulünce kendisini kucaklayıp öpmüştür. ${ }^{22}$

Şeyh ile halifesi arasındaki bu kucaklaşmada şeyh halifenin boynunun sol tarafını, halife de şeyhin sağ omuzunu öper. Halife şeyhinin elini de öptükten sonra ona saygısını ifade etmek için sağ eteğinin kuşaktan aşağısına yüzünü sürer. Halife şeyhin eteğine yüz sürerken fazla eğilmemeli, eğilirse de şeyh halifenin omuzundan tutarak kaldırmalıdır. Bu şekilde bir kucaklaşma müride hilafet verilip irşat faaliyetinde bulunacağ 1 yere gönderilirken ve irşat için bulunduğu yerden şeyhin yanına geldiğinde uygulanır. ${ }^{23}$

Şeyh halifesini kucaklayıp öptükten sonra "halifemiz ol" der, tarikatın şeyhlik silsilesini ve tevbenameyi eline verir. Yanına birkaç derviş de katarak irşat faaliyetinde bulunacağ 1 yere gönderir. Burası genellikle halifenin memleketidir. Bazen halife memleketi dışında başka bir yere de

\footnotetext{
${ }^{20}$ İlyas b. İsa Saruhani, Menâkıb-ı Mecdeddîn ve Âdâb-ı Sâlikîn, vr. 22b.

21 Sarı Abdullah Efendi, “Semerâtü'l-Fuâd”, Bayrâmî Melâmiliği’ne Dâir Melâmet Risâleleri, Haz. Abdurrezzak Tek, Bursa: Emin Yayınları, 2007, s. 81.

22 İlyas b. İsa Saruhani, Menâkıb-ı Mecdeddîn ve Âdâb-ı Sâlikîn, vr. $7 b$.

${ }^{23}$ İlyas b. İsa Saruhani, Menâkıb-ı Mecdeddîn ve Âdâb-ı Sâlikîn, vr. 5a-5b; İlyas b. İsa Saruhanî, Menakıb-ı
} Şeyh Mecd ed-din ve Adab-ı Salikin, Müst. Muhammed Emin Tevfik, 245x180-195x120 mm., 21 satır, Yazı Türü: Nesih, Atatürk Kitaplığı, Osman Ergin Türkçe Yazmaları No: 323, vr. 3a. 
gönderilebilmektedir. ${ }^{24}$ Burada şeyhin halifemiz ol ifadesi, kendisine değil; kendisinin de dahil olduğu örgütlenmeye ve hilafet zincirine vurgusu yapması bakımından önemlidir.

Halife irşat için bulunduğu yerde tarikatın ideal davranış ve düşünce kalıplarını, değerlerini insanlara aktarmakta ve onları uygun görülen şekilde eğitmektedir. Böylece tarikat merkezine bağlı olan yeni tekkeler açılmakta, tarikatın hem hızlı bir şekilde yayılması hem de propagandasının yapılması sağlanmaktadır. Burada faaliyette bulunan halife tarikata karşı sempati uyandırmakta ve müntesiplerin sayısını artırmaktadır. ${ }^{25}$

Hilafet merasimi esnasında şeyh müridine hilafetin simgesi olan ve belli anlamları bulunan birtakım eşyalar vermektedir. Bu eşyalar şemle, kemer, kuşak, seccade, alem ve çerağdır. Ayrıca şeyh yine bu merasim esnasında kendi ridasını halifesinin boynuna takar; tekbir eşliğinde kendi hırka ve tacını halifesine giydirir. Şeyhin halife tayin ettiği müridine kendi taç, hırka, seccade, tesbih ve asasını vermesi müridin irşat izninin olduğunu ve şeyhi öldükten sonra şeyhlik makamına geçebileceğini göstermektedir. Hacı Bayram öldükten sonra onun yerine geçmeye ve şeyhlik yapmaya en uygun kişinin kendisi olduğunu iddia ettiği belirtilen Akşemseddin, şeyhin söz konusu eşyalarının kendisinde olmasını bu iddiasına delil olarak sunmuştur. ${ }^{26}$

Şeyh, tarikat eğitimini tamamlayıp belli bir makama ulaşan müridinin halifeliğini söz konusu sembolik eşyalarla ilan edebileceği gibi sözlü olarak ya da yazılı bir belge ile de duyurabilmektedir. Önceleri, sembolik olarak verilen eşyalar veya sözlü ifadeler hilafetin verildiğini göstermek için yeterli görülmüştür. Ancak tasavvufun ve tarikatların yaygınlaşması ve itibar kazanması ile halifelik makamını hak etmeyenler, şeyhinden hilafet almamış olmasına rağmen halifelik iddia edenler çoğalınca sembolik eşyaların ve sözlü ifadelerin yanı sıra yazılı belgelere de ihtiyaç duyulmuş ve hilafetname adı verilen bu belgeler zamanla yaygınlaşmıştır. Tarikatta irşat iznini gösteren bu belgelere hilafetname, icazetname ve izinname gibi isimler verilmiştir (Uludağ, 2001: 513; Akpınar, 2000: 397). Konuyla ilgili olarak Mecdüddin İsa'nın hilafet aldığı merasime baktığımızda Mecdüddin İsa'ya hem hilafetin sembolü olan bazı eşyaların verildiğini hem sözlü olarak halifemiz ol denildiğini hem de yazılı bir belge verildiğini görmekteyiz. Böylece onun halifeliği etkili ve güçlü bir şekilde duyurulup meşrulaştırılmıştır.

Hilafetnameler önemli bazı işlevlere sahiptir. Her şeyden önce bu belgeler ait olduğu kişiyi tanıtmaktadır. Onun, tarikat bilgisini ve eğitimini kimden aldığını, silsile halinde bu bilginin kaynağının kime ulaştığını göstermektedir. Eğer bilginin halifeye ulaştığı silsile güvenilir ise sahip olduğu bilgi de güvenilir ve doğru kabul edilmektedir. Ayrıca hilafetnameler, kişinin edindiği bilgiyi aktarma yeteneğine ve yeterliliğine sahip olduğunu da göstermektedir. Çünkü bu belgeler tarikatın bilgisine tam anlamıyla vakıf olan kişilere verilmekte, o kişiyi tanıtma, onun yeteneğini ispatlama, tahsil derecesini ve bilgisinin türünü, disiplinli ve sistemli bir eğitim sonucunda bu bilginin edinildiğini ortaya koymaktadir (Atay, 1983: 101). ${ }^{27}$

\footnotetext{
${ }^{24}$ İlyas b. İsa Saruhani, Menâkıb-ı Mecdeddîn ve Âdâb-ı Sâlikîn, vr. 2b, 8b.

${ }^{25} \mathrm{H}$. Mustafa Genç'in İslami bakış açısı ile yazmış olduğu eserinde genel anlamda İslami teşkilatlanmaların merkez-şube ilişkisine dair ifadeleri, konuyu tarikatlar özelinde ele alırken bize de fikir vermiştir. Bkz.: (Genç,
} 1997: 103-105).

${ }^{26}$ İlyas b. İsa Saruhani, Menâkıb-ı Mecdeddîn ve Âdâb-ı Sâlikîn, vr. 2b, 8b; Sarı Abdullah Efendi, "Semerâtü’lFuâd”, Bayrâmî Melâmiliği'ne Dâir Melâmet Risâleleri, s. 81-83.

${ }^{27}$ Ayrica bkz.: (Güngör, 1982: 101). 
Bilginin kimden alındığını gösteren hilafetnameler ayrıca kişiyle ilgili olumlu bir önyargı da oluşturmaktadır. Hilafetnameyi alan kişi böylece bilgiyi edindiği kişinin itibarına ve saygınlığına da ortak olmaktadır. Bilgiyi aldığ kişi ve aynı zamanda silsilesinde bulunan kişiler hakkında nasıl bir algı mevcutsa halife hakkında da benzer bir algı oluşmaktadır. O kişilerin itibarlı ve kutsal kabul edilmesi hilafetnameyi alan kişiye de itibar ve kutsallık sağlamaktadır.

\section{Halifetü'l Hulefa}

Şeyh hayatta iken hak ettiğini düşündüğü, manevi anlamda yeterli gördüğü kişi veya kişilere hilafet verir. Belli ritüellere bağlı olarak şeyhinden hilafet alan mürit başka bir yerde irşat için görevlendirilir ve burada şeyhi adına insanları irşat eder, şeyhi ile irtibatını da sürdürür. Bir şeyhin birden fazla halifesi olabilir ve şeyh öldükten sonra bunlardan her biri bulunduğu yerde şeyhliğe devam eder. Bu halifelerden biri diğerleri arasında öne çıkıp ölen şeyhin yerine geçerse bu halifeye halifetü'l hulefa adı verilir. Şeyh ölmeden önce yerine kimin geçeceğini ya açıç̧a bildirir ya da bazı remizlere başvurur. Bazen de hiçbir açıklama veya işaret olmaz ki o zaman da kıdemi, bilgisi, liyakati, hitabeti, otoritesi, temsil gücü gibi özellikleri dolayısıyla uygun görülen bir kişi şeyhin yerine geçer. Müritler ve diğer halifeler şeyhin yerine geçen halifenin etrafında toplanır. Bazen de müritler birden fazla halifenin etrafında toplanır ki bu gibi durumlarda tarikatın kolları meydana gelir (Uludağ, 1997: 300).

Şeyh, yerine geçmesini istediği halifeye karşı diğerlerinden daha farklı bir tavır takınmaktadır. Ona karşı olan tavır ve davranışları onu kendi yerine halef bıraktığının işareti olarak algılanır. Vefatı halinde cenaze işleri ile kimin ilgileneceğine, cenaze namazını kimin kıldıracağına dair şeyhin yapmış olduğu vasiyet, varisi belirleme konusunda şeyhin başvurduğu en yaygın işaretlerdir (Uludağ, 1997: $300)$.

Kendi yerine geçecek olan halifeyi belirleme konusunda Hacı Bayram'ın da çeşitli remizlere başvurduğu belirtilmektedir. Hacı Bayram'ın, ölüm anında su istemesi ve Akşemseddin'in getirdiği suyu içmeyip Ömer Dede'nin getirdiği suyu içmesi ve bir miktarını da Ömer Dede'ye içirmesi Melamîler tarafından posta oturacak halifenin Ömer Dede olduğuna işaret olarak değerlendirilmiştir. ${ }^{28}$

Bayramî tarikatında tek bir halifenin etrafında toplanıldığı durumlarda diğer halifeler şeyhin yerine geçen halifeye biat etmez ve onun elinden de tevbe almazlar. Bu kişiler zaten eğitimini tamamladığı için başta bulunan halifeyi kabul eder, ona saygı duyar, onunla irtibatı kesmeden bulundukları yerde yine kendi müritlerini yetiştirirler ve ihtiyaç duyduklarında da daha iyi bir eğitim için kendi müritlerini ona göndermekte bir sakınca görmezler. ${ }^{29}$ Konuyla ilgili bir anlatıda nakledildiğine göre aynı tarikattan iki halife Mecdüddin İsa'yı ziyarete geldiğinde onun manevi bakımdan kendilerinden çok daha üstün olduğunu anlamışlar ve ona tabi olup onun elinden tövbe almak istemişlerdir. Mecdüddin İsa ise aynı şeyhten hilafet aldıkları için bunun uygun olmadığını şu ifadelerle ortaya koymuştur:

${ }^{28}$ La' lîzâde Abdülbâkî, "Sergüzeşt”, Bayrâmî Melâmiliği’ne Dâir Melâmet Risâleleri, Haz. Abdurrezzak Tek, Bursa: Emin Yayınları, 2007, s. 130.

29 Örneğin Muhammed Çelebi, müridi Mecdüddin İsa'yı daha iyi bir eğitim alması için aynı tarikattan Şeyh Kasım’a göndermekte herhangi bir sakınca görmemiştir. İlyas b. İsa Saruhani, Menâkıb-ı Mecdeddîn ve Âdâb-ı Sâlikîn, vr. 2b-3a. 
Bu fakîr dahi sizlere tevbe vermeye lâyık değil; zîrâ pîrlerimiz halîfelerindensiz, maksûd birbirimize hemân tabiiyyettir ve teslîmdir, tevbeden dahi murâd şimden gerü kesreti götürelim, vahdette olalım, derviş̧ler dahi yeksân gözlesinler cümlemiz. ${ }^{30}$

$\mathrm{Bu}$ ifadeler tarikat içinde birliğe vurgu yapması bakımından önemlidir. Halifeler farklı yerlerde irşat faaliyetinde bulunabilirler ama aralarında uygulama ve inanç noktasında birlik ve ortaklık söz konusudur, irtibat ve iletişimleri ise sürmektedir.

\section{Halifenin Şeyh Olmast: Kutsal Zincire Dahil Olma}

Şeyh hayatta iken uygun gördüğü müridine hilafet verip irşat vazifesiyle çeşitli yerlere gönderir. Şeyh hayatta olduğu sürece bu kişilere halife denir, şeyh öldükten sonra ise halifeler şeyh adını alır. ${ }^{31}$

Şeyh hayatta iken halifeler görevli oldukları yerde dervişleri eğitir, hatta şeyh kendisine gelen talibi çeşitli gerekçelerle halifesine bile gönderebilir. Nitekim Akşemseddin kendisinden tarikat eğitimi almak isteyen bir kişiyi, yaşlılığını gerekçe göstererek halifesi İbrahim Tennurî’ye (ö. 1482/83) göndermiştir. ${ }^{32} \mathrm{Bu}$ halifeler şeyhlerinin izni ile irşat faaliyetlerinde bulunsalar da şeyhleri ölmeden kendilerine bir halef tayin etmezler. Metinlerde bu konuda açık bir men ediş söz konusu değildir; ancak böyle bir durum halifenin "edebi terk etmesi”" şeklinde değerlendirilmektedir. ${ }^{33}$ Dolayısıyla BayramîŞemsî tarikatında halifenin şeyhi hayatta iken irşada izni vardır ancak halife tayin etme yetkisi bulunmamaktadır.

Halifenin şeyhliği hususunda dikkat çeken bir nokta da birden çok tarikattan hilafet alan müridin istediği ve uygun gördüğü tarikatın kurallarına göre şeyhlik yapması, irşat faaliyetlerinde bulunmasıdır. Mürit tek bir tarikattan hilafet alabildiği gibi istediği takdirde başka tarikatlardan da eğitimini tamamlayıp hilafet alabilir. Nakledildiğine göre Şeyh Hüsam on iki tarikatın hepsinden eğitim almış ve hepsinden de kendisine hilafet verilmiştir. Ancak o Bayramî tarikatında gördüğü cezbe, marifet ve kemali diğerlerinde görmediği için Bayramî tarikatı kisvesini tercih etmiş ve kendisine bağlananları da Bayramî tarikatının usullerine göre eğitmiştir. ${ }^{34}$

\section{Hilafet Verme Geleneğinin Fonksiyonlart}

Hilafet verme geleneğinin hem tarikatın örgütsel yapısı hem selef hem de bu statüyü elde eden kişi açısından önemli işlevler üstlendiği söylenebilir. Geleneğin, tarikatın örgütsel yapısındaki en önemli

\footnotetext{
${ }^{30}$ İlyas b. İsa Saruhani, Menâkıb-ı Mecdeddîn ve Âdâb-ı Sâlikîn, vr. 61a-62b.

${ }^{31}$ İlyas b. İsa Saruhani, Menâkıb-ı Mecdeddîn ve Âdâb-ı Sâlikîn, vr. 21 a.

${ }^{32}$ Bayramiye Tarikatı Menakıbı: Hacı Bayram Veli ve Halifeleri: el-Hâcı Bayrâm Sultân, Akşemseddîn, Şeyh İbrâhîm, Şeyh Kâsım Efendi, Şeyh Îsa Efendi, Şeyh Hüsâm Efendi, Şeyh Bahrî Efendi, Şeyh Alî Efendi, Fâtıma-i Menemeniyye, s. 47.

33 İlyas b. İsa Saruhani, Menâkıb-ı Mecdeddîn ve Âdâb-ı Sâlikîn, vr. 120b.

${ }^{34}$ Bayramiye Tarikatı Menakıbı: Hacı Bayram Veli ve Halifeleri: el-Hâcı Bayrâm Sultân, Akşemseddîn, Şeyh İbrâhîm, Şeyh Kâsım Efendi, Şeyh Îsa Efendi, Şeyh Hüsâm Efendi, Şeyh Bahrî Efendi, Şeyh Alî Efendi, Fâtıma-i Menemeniyye, s. 68.
} 
işlevi yetki ve otoritenin sorunsuz bir şekilde en uygun kişiye devredilmesini sağlamasıdır. İdare mekanizmasının sorunsuz bir şekilde el değiştirip sürekliliğin sağlanmasında ve böylece örgüt içi birlik ve ahengin devamında hilafet verme geleneğinin önemli bir yeri bulunmaktadır. Ayrıca tarikat benzeri örgütlenmelerin varlığı lidere bağlı olduğu için halife tayininin tarikat için hayati bir öneme sahip olduğunu söylemek yanlış olmayacaktır. ${ }^{35}$

Bu geleneğin tarikat için diğer önemli bir işlevi de tarikatın yaygınlaşmasını ve büyük bir kitleye ulaşmasını sağlamasıdır. Bir tarikatın ne kadar çok halifesi varsa tarikat o kadar geniş coğrafyaya yayılacak demektir. Çünkü bu halifeler irşatla görevli kişilerdir ve onların, şeyhin olduğu coğrafyada irşatta bulunması ayıp sayılmaktadır. Farklı coğrafyalarda şeyhin izni ile insanları irşat eden halifeler tarikata müntesip ve sempatizan da kazandırmakta ve insanları tarikatın ideallerine, uygun gördüklerine göre yetiştirmektedir.

Halef tayininin selef açısından önemli işlevi ise öldükten sonra da kendisini temsil edecek birini veya birilerini yetiştirmiş olmasıdır. Böylece o düşünce ve ideallerini temsil edecek ve yaşatacak en uygun kişiyi/kişileri belirlemiştir. Ayrıca bir tarikatta halife sayısının çok olması, pek çok müridin, şeyhlik seviyesinde yetişmiş olduğunu göstermek yönüyle şeyhin etki ve başarısına işaret etmekte; aynı zamanda tarikatın ideallerini anlatmaya mezun, irşat yetkisine sahip, yetişmiş insan gücünün varlığını göstermektedir.

Hilafet verme geleneği bu statüyü elde eden kişi için de önemli işlevler üstlenmektedir. Her şeyden önce halife saygın, güvenilir ve kutsal nitelikli bir konuma sahip olmaktadır. Ona bu konumu kendisinin de dahil olduğu hilafet zinciri sağlamaktadır. Tarikat mensupları halifelik silsilesini önemsemekte ve konuyla ilgili bilgi sahibi olmak istemektedir. ${ }^{36}$ Halifeliğin kimlerden kimlere verildiğine dair bilgi, tarikatın bilgisinin kaynağını da ortaya koyacaktır. Bu silsiledeki şahısların güvenilir olması bilginin de güvenilir olması anlamına gelmektedir. Bu nedenle bilgiye muhatap olacak kişiler bilginin kaynağına ve bağlanacakları kişinin silsilesine dair bilgiye sahibi olmak istemektedir.

\section{Sonuç ve Değerlendirme}

Tasavvufta belli bir temele dayandırılan halife tayin etme geleneği hemen her tarikatta karşımıza çıkmaktadır. Tarikatlarda bu gelenekle ilgili inanç ve uygulamalarda bazı ortak noktalar ve pek çok farklılık bulunmaktadır. Hatta aynı tarikat içinde, ayrı kollarda ya da farklı zamanlarda farklı uygulamalar olabilmektedir. Bu nedenle her bir tarikatta söz konusu gelenekle ilgili yapılacak olan monografik çalışmalar tarikatın varlığını ve nüfuzunu devam ettirmesi sürecinde önemli olan bu geleneğin hem anlamı, uygulanışı hem de dinî, psikolojik ve sosyolojik arka planı hakkında genellemelere ulaşmamızı sağlayacaktır. Ayrıca bu tür çalışmalar tarikat içi düzen ve işleyişin kesintisiz olarak ve uygun görülen şekilde devamı ve yayılışı arzusunun göstergesi olan halife tayini konusunun mantığının anlaşılabilmesi ve teorik olarak işlenebilmesi için zemin de oluşturacaktır.

\footnotetext{
${ }^{35}$ Tarikatın metinlerinde de hilafet verme geleneğinin bu işlevine değinilmekte, şeyh öldükten sonra halifelerin, tarikatın dağılmasın engellediği ve eski nizamı ile devamını sağladığı belirtilmektedir. Bkz.: İlyas b. İsa Saruhani,
} Menâkıb-ı Mecdeddîn ve Âdâb-ı Sâlikîn, vr. 38b.

${ }^{36}$ İlyas b. İsa Saruhani, Menâkıb-ı Mecdeddîn ve Âdâb-ı Sâlikîn, vr. 2a; İlyas b. İsa Saruhanî, Menakıb-ı Şeyh

Mecd ed-din ve Adab-1 Salikin, vr. 1a. 
Bu konu özellikle siyasi ve tasavvufi alanda işlenmiştir. Halife ister siyasi ister dinî-tasavvufi alanda olsun "daha önce gerçekleştirilmiş bir tecrübenin ve otoritenin devrine" vurgu yapmaktadır. Tecrübesi ve otoritesi devralınan ise, silsile halinde geriye gidildiğinde, Hz. Muhammed'dir. Bu nedenle her iki alanda da halifelik ayrıcalıklı ve kutsal bir statüdür. Halifenin dinî-tasavvufi alanda tasarruf yetkisi ise pratikte kendi örgütü ile sınırlıdır. Her halife uygulamada kendi örgütünün üyelerini idare eder. Halk arasında ise onun otoritesinin ve tasarruf yetkisinin her iki dünyada tüm yaratılmışlar için söz konusu olduğu algısı yaygındır ve halkın bu algısını menkıbeler açık bir şekilde yansıtmaktadır.

Halife tayin etme geleneği Bayramî-Şemsî tarikatı metinlerinde, Hz. Muhammed'in Hz. Ali'ye belli konularda hilafet vermesine dayandırılarak hem bu uygulamaya meşruiyet kazandırılmış hem de şeyh ile halifesi arasındaki ilişki, Hz. Muhammed ile Hz. Ali arasındaki yakınlığa benzetilmiştir. Böylece her bir halife şeyhinin halefi olmakla birlikte silsile itibariyle aynı zamanda Hz. Muhammed'in de halefi olup saygin ve kutsal bir konum elde etmektedir.

$\mathrm{Bu}$ tarikatta hilafet verme geleneğinin tesadüfe bırakılmayıp belli şartlara bağlandığı görülmüştür. Bu şartlar aynı zamanda tarikatta idealleştirilen insan tipini de yansıtmaktadır. BayramîŞemsî tarikatında halife olabilmenin ilk şartı kamil bir şeyh rehberliğinde tarikat eğitimini tamamlayıp şeyhin de bulunduğu tecelli-i Zat makamına ulaşmaktır. Bu makamda selef ile halef özdeşleşmekte ve bu, Hz. Muhammed'in Hz. Ali'ye sen bendensin, ben de sendenim demesine benzetilmektedir. Bu makama ulaşmasına rağmen kadınlara, hünsalara, âmâlara ve ümmilere hilafet verilmesi ise pek tercih edilmemektedir. $\mathrm{Bu}$ durum, tarikatın geleneğin uygulanması noktasında cinsî ve fiziki yönden ayrımcılık yaptığı şeklinde değerlendirilebilir. Ancak bu cinsî ve fiziki farklılı̆̆ bırakıp bu kişileri halifelikten tamamen men etmemesi tarikatın toplumun farklı kesimlerine karşı kuşatıcı, farklılığa nispeten de olsa hoşgörülü ve her cinsiyetten insana kapı açar nitelikte olduğunu da göstermektedir. Burada dikkat çekici bir husus da tarikat eğitimini tamamlaması şartıyla ümmi olan bir kişinin bile halifelikten tamamen men edilmemesi ancak tarikat bilgisinin cahili olan kişi şeyhin oğlu dahi olsa soy ayrımcılığı yapılmayıp halifeliğine izin verilmemesidir. Halife olabilmek için zikredilen bu şartlar bize Bayramî-Şemsî tarikatında şu niteliklere sahip bir insanın idealleştirildiğini göstermiştir: erkek olan, fiziki anlamda bir engeli bulunmayan, ümmi olmayan, tarikatın bilgisine tam anlamıyla vakıf olan, tarikat eğitimini tamamlayıp tecelli-i Zat makamına ulaşan.

Hilafetin ilanı selef ile halef arasındaki yakınlığı ve halifenin diğer müritler arasındaki ayrıcalıklı konumunu gösteren bir ritüelle gerçekleşmektedir. Şeyh bu ritüellerle birden fazla halife çıkarabilmekte ya da hiç halife tayin etmemektedir. Şeyh kendisine halef tayin ederek bir bakıma gücünü de paylaşmaktadır ancak bu halifelerden hiçbiri şeyh hayatta iken onun gücü ve yetkisi dışında davranmamaktadır. Zira halifeye de güç ve iktidarını kazandıran şeyhinin ardına eklemlendiği hilafet zinciridir. Şeyh öldüğü takdirde bu halifelerden biri ya şeyhin isteği üzerine ya da belli nitelikleri ile ön plana çıkıp şeyhin yerine geçmektedir. Şeyh, yerine geçmesini istediği halifeyi bazen doğrudan söylemekte bazen çeşitli imalarda bulunmakta bazen de hiç bir belirlemede bulunmamaktadır. BayramîŞemsî tarikatında bu şekilde ön plana çıkan halifenin diğer halifeler üzerinde hakimiyet iddia etmediği, onların şeyhliklerini kabul edip tarikat içi uyum ve birlikteliğe önem verdiği görülmüştür.

Hilafet verme geleneğinin Bayramî-Şemsî tarikatının örgütsel yapısında yetki devrinin sorunsuz bir şekilde gerçekleşmesi, tarikatın geniş bir kitleye ulaşması, örgüt içi bütünlüğün korunması gibi işlevler üstlendiği; şeyhin başarısını ve tarikatın kalifiye üye sayısını gösterdiği; halifelik statüsünün kişiye güvenilirlik, saygınlık ve kutsallık gibi nitelikler kazandırdığı tespit edilmiştir. Bu geleneğin diğer 
tarikatlardaki algılanma ve uygulanma biçiminin de araştırılması halifelikle ilgili daha sağlam tespitlerde ve değerlendirmelerde bulunulmasını sağlayacaktır.

\section{REFERENCES}

- Akpınar, C. (2000). "İcâzet", Türkiye Diyanet Vakfi İslâm Ansiklopedisi, C. 21, İstanbul: Türkiye Diyanet Vakfı Yayınları, s. 393-400.

- Atay, H. (1983). Osmanlılarda Yüksek Din Eğitimi: Medrese Programları - İcazetnameler Islahat Hareketleri, İstanbul: Dergah Yayınları.

- Bayramiye Tarikatı Menakıbı: Hacı Bayram Veli ve Halifeleri: el-Hâcı Bayrâm Sultân, Akşemseddîn, Şeyh İbrâhîm, Şeyh Kâsım Efendi, Şeyh Îsa Efendi, Şeyh Hüsâm Efendi, Şeyh Bahrî Efendi, Şeyh Alî Efendi, Fâtıma-i Menemeniyye, Haz. Zehra Hamarat, İstanbul: Dergâh Yayınları, 2015.

- Bilgin, N. (2003). Sosyal Psikoloji Sözlüğü: Kavramlar, Yaklaşımlar, İstanbul: Bağlam Yayınc1lik.

- Cebecioğlu, E. (2004). Tasavvuf Terimleri ve Deyimleri Sözlüğü, 2. bs., İstanbul: Anka Yayınları.

- Emir Hüseyin Enîsî (2011). Menâkıb-1 Akşemseddîn, Haz. Bilâl Aktan, Mustafa Güneş, İstanbul: H Yayınları.

- Freedman, J. L. - D. O. Sears - J. M. Carlsmith (2003). Sosyal Psikoloji, Çev. Ali Dönmez, 4. bs., Ankara: İmge Kitabevi.

- Freyer, H. (1964). Din Sosyolojisi, Çev. Turgut Kalpsüz, Ankara: Ankara Üniversitesi İlahiyat Fakültesi Yayınları.

- Genç, H. M. (1997). İslam'da ve İdeolojilerde Teşkilat ve Teşkilatçl1ık, Samsun: Akabe-Biat Yayınları.

- Güngör, E. (1982). İslâm Tasavvufunun Meseleleri, İstanbul: Ötüken Neşriyat.

- Hoyladı, A. (2015). İslam Hukukunda Hilafetin Kureyşiliği Tartışmaları ve Hindistan Örneği, İstanbul: Rağbet Yayınları.

- Işın, E. (1994). "Melamîlik", Dünden Bugüne İstanbul Ansiklopedisi, C. 5, İstanbul: Ana Basim, s. 380-386.

- İlyas b. İsa Saruhani, Menâkıb-1 Mecdeddîn ve Âdâb-1 Sâlikîn, Müst. Ahmed, 265x160mm., 19 satır, H.1161, Mısır Milli Kütüphanesi Türkçe Yazmaları, ez-Zekiye-Mahtutatu Farisiyye ve Türkiyye.

- İlyas b. İsa Saruhanî, Menakıb-1 Şeyh Mecd ed-din ve Adab-1 Salikin, Müst. Muhammed Emin Tevfik, 245x180-195x120 mm., 21 satır, Yazı Türü: Nesih, Atatürk Kitaplığı, Osman Ergin Türkçe Yazmaları No: 323.

- Kızılçelik, S. - Y. Erjem (1994). Açıklamalı Sosyoloji Terimler Sözlüğü, Ankara: Atilla Kitabevi.

- Krech - Crutchfield - Ballachey (1971). Cemiyet İçinde Fert, Çev. Mümtaz Turhan, C. 2, İstanbul: Milli Eğitim Basımevi.

- La'lîzâde Abdülbâkî (2007). "Sergüzeşt”, Bayrâmî Melâmiliği’ne Dâir Melâmet Risâleleri, Haz. Abdurrezzak Tek, Bursa: Emin Yayınları.

- Ocak, A. Y. (1998). Osmanlı Toplumunda Zındıklar ve Mülhidler (15. - 17. Yüzyıllar), İstanbul: Tarih Vakfı Yurt Yayınları.

- Ozankaya, Ö. (1975). Toplumbilim Terimleri Sözlüğü, Ankara: Türk Dil Kurumu Yayınları. 
- Öngören, R. (2010). "Şeyh”, Türkiye Diyanet Vakfi İslâm Ansiklopedisi, C. 39, İstanbul: Türkiye Diyanet Vakfi Yayınları, s. 50-52.

- Sarı Abdullah Efendi (2007). "Semerâtü'l-Fuâd", Bayrâmî Melâmiliği’ne Dâir Melâmet Risâleleri, Haz. Abdurrezzak Tek, Bursa: Emin Yayınları.

- Schein, E. H. (1978). Örgüt Psikolojisi, Çev. Mustafa Tosun, Ankara: Türkiye ve Orta Doğu Amme İdaresi Enstitüsü Yayınları.

- Tolan, B. - G. İsen - V. Batmaz. (1985). Ben ve Toplum: Sosyal Psikoloji I, Ankara: Teori Yayınları.

- Türcan, T. (2007). "Hilâfet Teorisindeki Dönüşümde Türk Siyaset Düşünürlerinin Rolü Yasamanın Sekülerleşmesi Bağlamında Bir İnceleme-”, Uluslararası Türk Dünyasının İslamiyete Katkıları Sempozyumu: Bildiriler, Isparta: S.D.Ü İlâhiyat Fakültesi Yayınları, s. 297-304.

- Türkçe Sözlük, Haz. Şükrü Halûk Akalın, vd., 11. bs., Ankara: Türk Dil Kurumu Yayınları, 2011.

- Uludağ, S. (1997). "Halife", Türkiye Diyanet Vakfı İslâm Ansiklopedisi, C. 15, İstanbul: Türkiye Diyanet Vakfı Yayınları, s. 299-300.

- Uludağ, S. (2001). "İzin (Tasavvuf)", Türkiye Diyanet Vakfi İslâm Ansiklopedisi, C. 23, İstanbul: Türkiye Diyanet Vakfi Yayınları, s. 512-513.

- Uludağ, S. (2006). Tasavvufun Dili: Mürşid - Mürîd - Yol, C. 1, İstanbul: Mavi Yayıncılık.

- Uludağ, S. (2012). Tasavvuf Terimleri Sözlüğü, İstanbul: Kabalcı Yayıncılık.

- Weber, M. (2004). Sosyolojinin Temel Kavramları ve Meslek Olarak İlim, Çev. Medeni Beyaztaş, İstanbul: Efkar Yayınları.

- Yılmaz, M. (2008). Kültürümüzde Arapça ve Farsça Asıllı Vecizeler Sözlüğü, C. 1, İstanbul: Sütun Yayınları.

- Zel, U. (2006). Kişilik ve Liderlik: Evrensel Boyutlarıyla Yönetsel Açıdan Araştırmalar, Teoriler ve Yorumlar, 2. bs., Ankara: Nobel Yayın Dağıtım. 